\title{
Herbicidal Selectivity of Root-Applied Simetryne: Its Absorption, Translocation and Metabolism in Gramineous Plants
}

\author{
Hiroshi Matsumoto and Kozo Ishizuka \\ Institute of Applied Biochemistry, The University of Tsukuba, \\ Ibaraki 305, Japan
}

Selective action of foliar-applied simetryne $[2,4$-bis (ethylamino)-6-(methylthio)-s-triazine] was studied as previously reported (3). The rate of its absorption by shoots was found much higher in barnyardgrass (susceptible) than in rice (tolerant). Although few differences were observed in the rates of translocation and degradation, the metabolic pathways were remarkably different. Therefore, it was concluded that the differential pathways of metabolism, as much as the rate of absorption, might contribute to the selectivity of foliar-applied simetryne.

In an attempt to clarify whether the selective mechanism of root-applied simetryne functions in the same way as foliar-applied, investigations were conducted on the absorption, translocation and metabolism of simetryne applied to the roots of gramineous plants.

\section{Materials and Methods}

\section{(1) Plant Materials}

Seeds of rice (Oryza sativa L. cv. Nihonbare), barnyardgrass (Echinochloa crusgalli Beauv. var. orizicola Owhi), corn (Zea mays L.), wheat (Triticum aestivum L.), finger millet (Eleusine coracana Gaertn.) and large crabgrass (Digitaria adscendens Henr.) were germinated in an incubator at $25^{\circ} \mathrm{C}$ for two days and grown to the first leaf stage. The seedlings were then transferred to plastic pots containing Kasugai nutrient solution for water culture, and grown to the third leaf stage in a greenhouse under natural light with controlled temperatures of $29^{\circ} \mathrm{C}$ daytime and $22^{\circ} \mathrm{C}$ during the night. Imperfect leaf of rice was omitted in the leaf stage counting. Plants of the same growth stage were used in all experiments.

\section{(2) Application of Simetryne}

Roots of intact plants of six gramineous species were placed in $500 \mathrm{ml}$ of a simetryne aqueous solution at two designated concentrations for 1 hour. The solutions contained 1 $\%$ acetone as a solvent for simetryne. After the treatment the roots were thoroughly washed with distilled water and the plants were transferred to a simetryne-free nutrient solution for further growth in the greenhouse. Seven days after treatment, the plants were harvested, divided into shoots and roots, and their fresh and dry weights were determined. Each treatment was replicated three times using ten plants, except that for corn and wheat five plants were used. This experiment was conducted in October, 1979.

\section{(3) Absorption and Translocation of ${ }^{14} \mathrm{C}$ - Simetryne}

Rice (tolerant) plants and barnyardgrass (susceptible) plants were used for this study. The roots of both plants were placed in a $0.40 \mathrm{ppm} \quad{ }^{14} \mathrm{C}$-simetryne solution (specific activity $17.0 \mu \mathrm{Ci} / \mathrm{mg}$ ) which had been mixed with $1 \%$ acetone. All treatments were carried out in a growth chamber maintained at $30^{\circ} \mathrm{C}$ with $67 \%$ relative humidity and 20 klux of 
light intensity. After the designated periods of absorption, plants were removed from the ${ }^{14} \mathrm{C}$-simetryne solution and the roots were thoroughly washed with distilled water and blotted with tissue paper. The plants were then divided into shoots and roots. After being air-dried at $90^{\circ} \mathrm{C}$ for 24 hours, they were weighed and combusted in a sample combustion system (Aloka ASC-113). The ${ }^{14} \mathrm{C}$ radioactivity in shoots and roots was determined by a liquid scintillation spectrometer (Beckman LS-8100), and absorption and translocation rates were measured. Autoradiographs were prepared of the rice and barnyardgrass plants treated with ${ }^{14} \mathrm{C}$-simetryne $(2.2 \mu \mathrm{Ci} / 10 \mathrm{ml})$ through the roots for 1 or 3 hours.

\section{(4) Metabolism of ${ }^{14} \mathrm{C}$-Simetryne}

The roots of rice and barnyardgrass were placed in a $0.75 \mathrm{ppm}$ simetryne solution containing $6.4 \mu \mathrm{Ci} / 500 \mathrm{ml}$ of ${ }^{14} \mathrm{C}$-simetryne for 1.5 hours. Follwing absorption periods the plants were removed from the treated solution, rinsed with water and transferred to $100 \mathrm{ml}$ of a simetryne-free nutrient solution. This treatment was duplicated using 30 plants each time. At various intervals the plants were sampled, divided into shoots and roots, and homogenized with $10 \mathrm{ml}$ of $90 \%$ methanol per gram of tissue. Extraction was carried out three times using equal of volumes $90 \%$ methanol. Radioactivity of the combined extracts was determined and their methanol was evapolized in vacuo at $35^{\circ} \mathrm{C}$. The residual extracts were partitioned three times between dichloromethane and water. The radioactivity of the dichloromethane and aqueous phases was determined and assayed by thin-layer chromatography as described previously (3). Radioactivity of non-extractable residue was determined by the sample combustion methods.

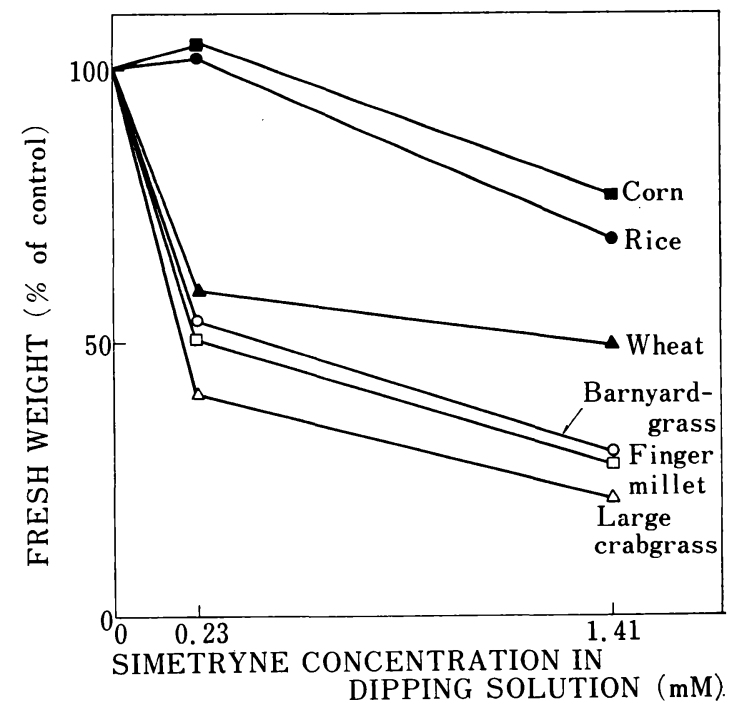

Fig. 1. Effect of root-applied simetryne on growth of gramineous plants.

The metabolic study was repeated and confirmed with ${ }^{14} \mathrm{C}$-simetryne of $3.5 \mu \mathrm{Ci} / 500$ $\mathrm{ml}$ aqueous solution and thin-layer chromatography was done with the dichloromethanesoluble fractions in the nutrient solution, in addition to those in the shoots and roots.

\section{Results and Discussion}

\section{(1) Effects of Root-Applied Simetryne on Plant Growth}

Herbicidal activity of root-applied simetryne was studied in six plants species (Fig. 1). Among these species, corn and rice were found the most tolerant to simetryne. Finger millet, large crabgrass and barnyardgrass were susceptible and showed symptoms of simetryne injury at a concentration of 0.23 $\mathrm{mM}$ and were almost all killed at $1.41 \mathrm{mM}$ seven days after treatment. Wheat was intermediate to tolerant. It was observed that simetryne showed great selectivity among gramineous plants. Rice was selected as a tolerant plant and barnyardgrass as a susceptible one for the present experiments. 


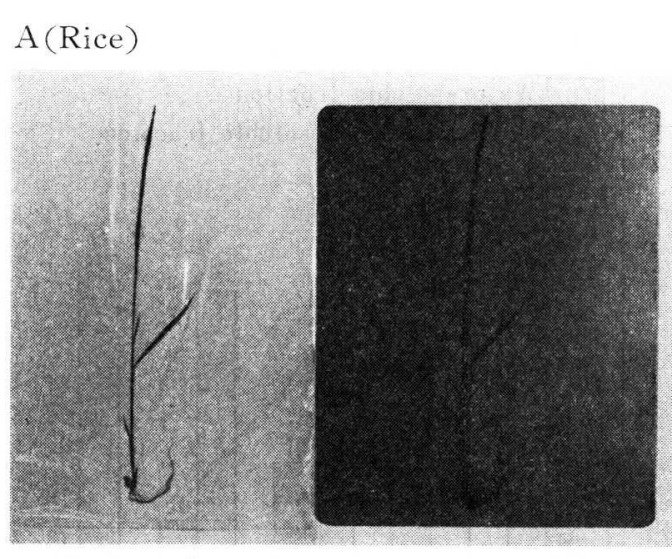

B (Barnyardgrass)

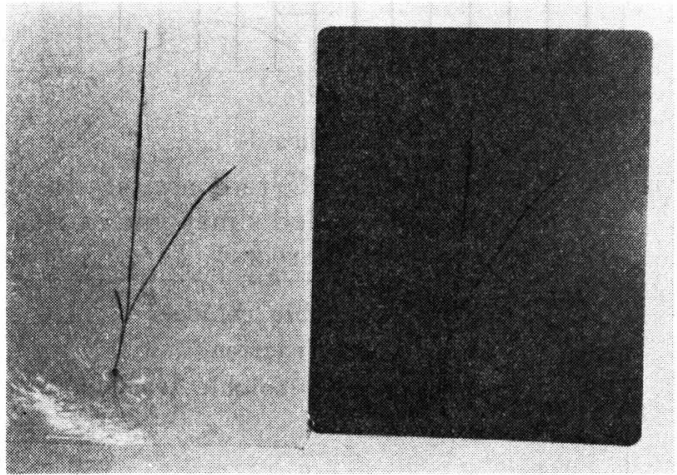

Fig. 2. Photographs (left) and Autoradiographs (right) of rice and barnyardgrass. Upper plate (A) is of a rice plant and lower (B) is barnyardgrass. These plants had absorbed ${ }^{11} \mathrm{C}$-simetryne solution through their roots for 3 hours.

\section{(2) Asorption and Translocation of ${ }^{14} \mathrm{C}-$ Simetryne}

Autoradiographs showed that ${ }^{14} \mathrm{C}$ derived from labeled simetryne was rapidly translocated to the shoots of rice and barnyardgrass and that ${ }^{14} \mathrm{C}$ was evenly distributed all over the shoots (Fig 2).

The rates of absorption of ${ }^{14} \mathrm{C}$-simetryne by the roots of rice and barnyardgrass were similar (Fig. 3), while translocation rates from roots to shoots differed significantly especially during the short periods (Fig. 4). The rate of translocation was found higher in barnyardgrass than in rice. Since it was

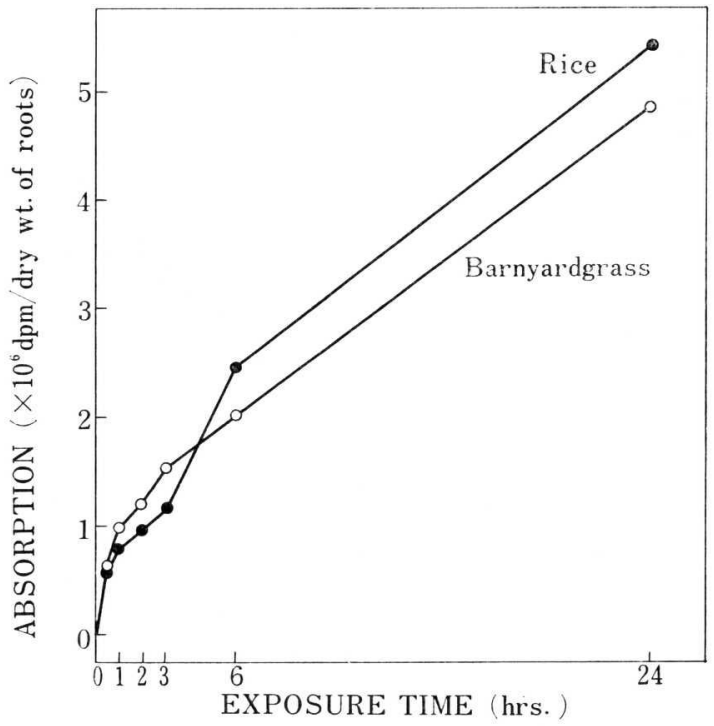

Fig. 3. Absorption of ${ }^{14} \mathrm{C}$-simetryne by roots of rice and barnyardgrass.

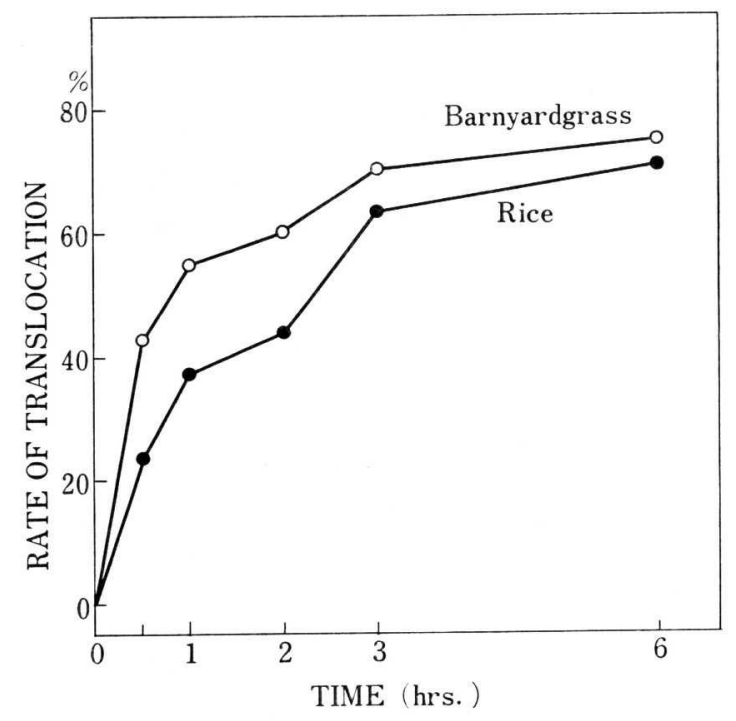

Fig. 4. Translocation of ${ }^{14} \mathrm{C}$ labeled simetryne from roots to shoots.

estimated by determining the total ${ }^{14} \mathrm{C}$ radioactivity in shoots and roots, the translocated chemicals could not be determined whether it was simetryne itself or its metabolites. The ${ }^{14} \mathrm{C}$ concentration in shoots was almost identical, but was slightly higher in barnyardgrass than in rice until 4 hours after the initial absorption (Fig. 5). It was considered that 


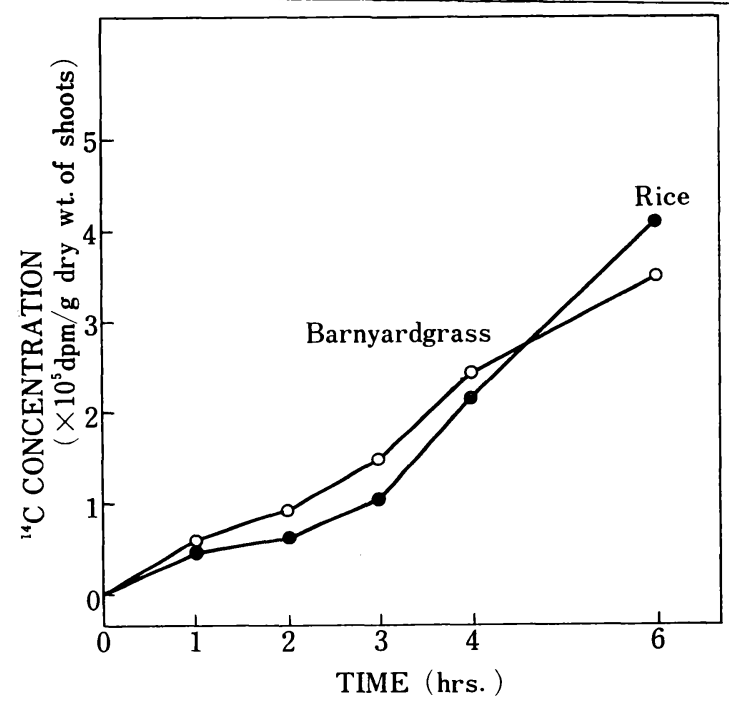

Fig. 5. Concentration in shoots of ${ }^{14} \mathrm{C}$ from labeled simetryne.

the faster translocation might reflect on the greater susceptibility of barnyardgrass. Thus, translocation from roots to shoots was concluded to be one of the factors determining the selectivity of root-applied simetryne.

\section{(3) Metabolism of ${ }^{14} \mathrm{C}$-Simetryne}

Both rice and barnyardgrass metabolized simetryne to water-soluble metabolites and methanol-insoluble residues in shoots and roots (Fig. 6 and 7 ), but rice converted simetryne in significantly greater amounts than did barnyardgrass. It was also more active than barnyardgrass in metabolizing simetryne in both shoots and roots. The roots of rice contained a larger percentage of total absorbed ${ }^{14} \mathrm{C}$ radioactivity than did the roots of barnyardgrass. Root-applied simetryne was retained for a longer period and in a greater percentage, allowing more time for reception of metabolic change before it was translocated to the shoots. Since the shoots are considered the primary site of action, this fact may contribute to the tolerance.

Greater release of absorbed ${ }^{14} \mathrm{C}$ radioactivity from the roots into the herbicide-free nutrient solution was observed. In rice, 54.1

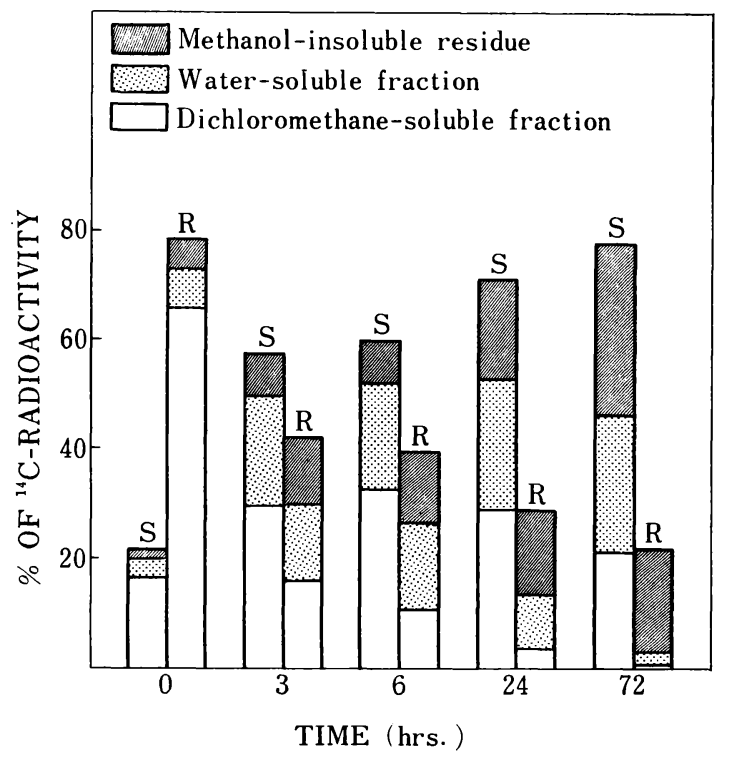

Fig. 6. Distribution of ${ }^{14} \mathrm{C}$-radioactivity from root-applied labeled simetryne in rice. ( $\mathrm{S}$ : shoots, $\mathrm{R}$ : roots)

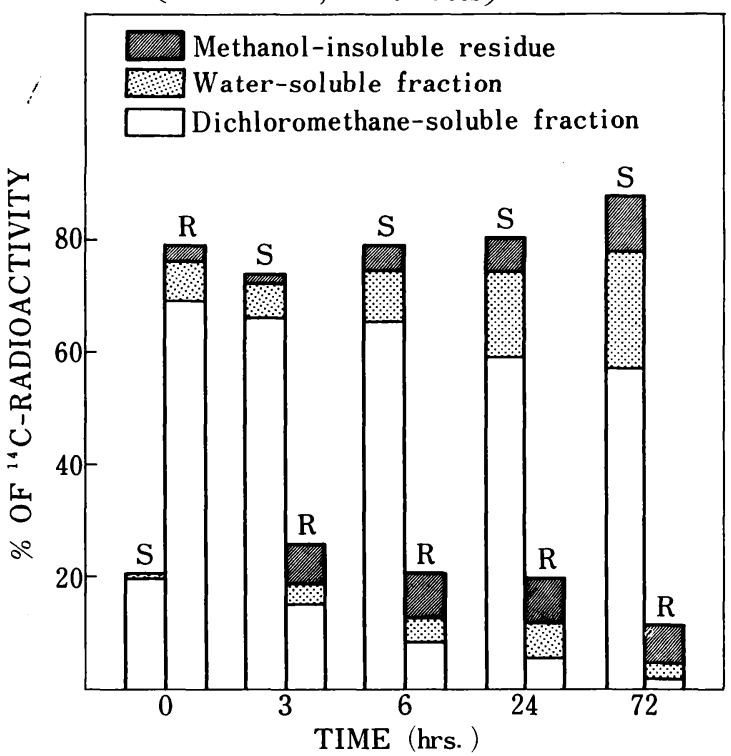

Fig. 7. Distribution of ${ }^{14} \mathrm{C}$-radioactivity from root-applied labeled simetryne in barnyardgrass. ( $\mathrm{S}$ : shoots, $\mathrm{R}$ : roots)

$\%$ and $28.2 \%$ of total absorbed radioactivity were detected in the nutrient solution 3 and 24 hours, respectively, after having been transferred. In barnyardgrass, the figures were $55.1 \%$ and $34.6 \%$ after 3 and 24 hours. The distribution of radioactivity in the nutrient 
Table 1. Distribution of ${ }^{14} \mathrm{C}$-radioactivity derived from root-applied ${ }^{14} \mathrm{C}$-simetryne in nutrient solution

\begin{tabular}{c|c|c|c|c}
\hline & \multicolumn{2}{|c|}{ Rice } & \multicolumn{2}{c}{ Barnyardgrass } \\
\hline \multicolumn{1}{c|}{ time(hrs. ) } & 3 & 24 & 3 & 24 \\
\hline $\begin{array}{l}\text { Dichloromethane- } \\
\text { soluble fraction }\end{array}$ & $74.7 \%$ & $33.8 \%$ & $81.1 \%$ & $62.2 \%$ \\
\hline $\begin{array}{l}\text { Water - soluble } \\
\text { fraction }\end{array}$ & 25.3 & 66.2 & 18.9 & 37.6 \\
\hline \multicolumn{1}{c}{ Total (\%) } & 100.0 & 100.0 & 100.0 & 100.0 \\
\hline
\end{tabular}

solution into dichloromethane-soluble and water-soluble fractions is shown Table 1. A remarkable increase in radioactivity was also detected in the water-soluble fraction of rice plant. Although photodecomposition of simetryne and the formation of 4,6-bis(ethylamino) $-s$-triazine in an aqueous solution were reported (4), it is believed that the absorbed simetryne degraded in roots and was released into the nutrient solution as a water-soluble compound.

The principal mode of action of $s$-triazine, especially chloro-s-triazine herbicides, seems to be an inhibition of photosynthesis $(1,5)$; therefore, it was considered that the selectivity was correlated to the extent to which a herbicide remains in its toxic form in the shoots of plants. The dichloromethane-soluble fraction of shoots, roots and nutrient solution in which unchanged simetryne was dissolved, was further investigated in detail by thin-layer
Rice

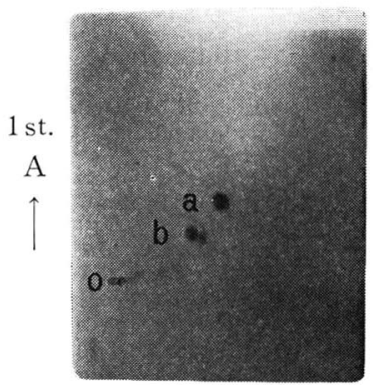

$\longrightarrow$ 2nd. B
Barnyardgrass

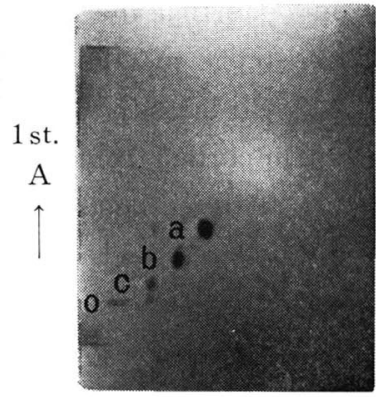

$\longrightarrow$ 2nd. B

Fig. 8. Dicloromethane-soluble metabolites of ${ }^{14} \mathrm{C}$-simetryne in shoots of rice and barnyardgrass 24 hours after treatment.

a : simetryne, b : mono-dealkylated simetryne, c : di-dealkylated simetryne, o : origin.

Thin-layer plates were developed di-dimensionally with (A) hexane : ethyl acetate $(2: 8)$ and (B) benzene : chloroform : ethyl acetate : n-propanol $(2: 1: 2: 1)$.

chromatography. The autoradiograms of the dichloromethane-soluble fractions showed the presence of simetryne, mono-dealkylated simetryne[2-amino-4-(ethylamino)-6-(methylthio) $-s$-triazine $]$, di-dealkylated simetryne $[2,4-$ diamino-6-(methylthio)-s-triazine] and other unknown compounds (Fig. 8). Percentages of these compounds are shown in Table 2.

The percentages of ${ }^{14} \mathrm{C}$ compounds in the dichloromethane-soluble fraction of nutrient solution were remarkably different in rice and barnyardgrass. Greater amounts of metabolites

Table 2. Distribution of ${ }^{14} \mathrm{C}$-radioactivity derived from root-applied ${ }^{14} \mathrm{C}$-simetryne in dichloromethane-soluble fraction

\begin{tabular}{|c|c|c|c|c|c|c|c|c|c|c|c|c|}
\hline \multirow[b]{3}{*}{ Time(hrs.) } & \multicolumn{6}{|c|}{ Rice } & \multicolumn{6}{|c|}{ Barnyardgrass } \\
\hline & \multirow{2}{*}{\multicolumn{2}{|c|}{$\begin{array}{l}\text { Nutrient } \\
\text { solution }\end{array}$}} & \multicolumn{2}{|c|}{ Roots } & \multicolumn{2}{|c|}{ Shoots } & \multicolumn{2}{|c|}{$\begin{array}{l}\text { Nutrient } \\
\text { solution }\end{array}$} & \multicolumn{2}{|c|}{ Roots } & \multicolumn{2}{|c|}{ Shoots } \\
\hline & & & 3 & 24 & 3 & 24 & & 24 & 3 & 24 & 3 & 24 \\
\hline Simetryne & $82.6 \%$ & $23.8 \%$ & $36.8 \%$ & $7.9 \%$ & $73.3 \%$ & $47.1 \%$ & $95.4 \%$ & $94.7 \%$ & $57.1 \%$ & $46.1 \%$ & $69.3 \%$ & $52.3 \%$ \\
\hline $\begin{array}{l}\text { Mono-dealkylated } \\
\text { simetryne }\end{array}$ & 6.2 & 46.3 & 18.4 & 36.8 & 8.9 & 30.6 & 4.6 & 5.3 & 7.8 & 16.7 & 20.6 & 36.1 \\
\hline $\begin{array}{l}\text { Di-dealkylated } \\
\text { simetryne }\end{array}$ & 8.3 & 13.2 & 5.0 & 7.4 & 12.8 & 5.1 & 0 & 0 & 13.9 & 15.0 & 4.3 & 7.0 \\
\hline Others & 2.9 & 16.7 & 39.8 & 47.9 & 5.0 & 17.2 & 0 & 0 & 21.2 & 22.2 & 5.8 & 4.6 \\
\hline Total $(\%)$ & 100.0 & 100.0 & 100.01 & 100.0 & 100.0 & 100.0 & 100.0 & 100.0 & 100.0 & 100.0 & 100.0 & 100.0 \\
\hline
\end{tabular}


were detected in rice. These results also indicate that the roots of rice have a greater simetryne metabolizing ability than those of barnyardgrass; the roots of rice seem to play an important role in its tolerance.

In rice shoots, unchanged simetryne was only $21.6 \%$ and $13.7 \%$ of the total ${ }^{14} \mathrm{C}$ radioactivity after 3 and 24 hours, respectively, those values were calculated from percentages of the chemical existing in the dichloromethane extracts. In barnyardgrass, $43.1 \%$ and $31.0 \%$ of unchanged simetryne were detected after 3 and 24 hours, respectively. Although the combined toxicity of other metabolites has not been identified, the concentrations of unchanged simetryne were remarkably different in the two types of plants. The high concentration of unchanged simetryne found in shoots of barnyardgrass was caused by the higher rate of translocation from roots to shoots and slower metabolism in both areas.

Effects of simetryne on the reduction of NADP, ATP generation and $\mathrm{O}_{2}$ evolution by photosynthetic reaction were surveyed (2). No significant difference in the two plant species was found. Considering the absorption, translocation and metabolism of simetryne as well as its effect on plant metabolism, we concluded that the selectivity of simetryne applied to roots was mainly due to the different metabolizing ability in shoots and roots and the differential rate of translocation to the shoots.

\section{Summary}

The selectivity pattern of root-applied simetryne $[2,4$-bis (ethylamino)-6-(methylthio)$s$-triazine] was studied in six gramineous plnat species. Simetryne had a great selectivity among these gramineous plants. Rice (Oryza sativa L.cv. Nihonbare) and corn (Zea mays L.) were tolerant, and finger millet (Eleusine coracana Gaertn.), large crabgrass (Digitaria adscendens Henr.) and barnyardgrass (Echinochloa crus-galli Beauv. var. oryzicola Owhi) were susceptible to simetryne. Wheat (Triticum aestivum L.) showed itself intermediate to tolerant. In order to clarify the selectivity of simetryne, its absorption, translocation and metabolism in rice and barnyardgrass were investigated. The rates of absorption of ${ }^{14} \mathrm{C}$ simetryne were almost similar, but the rate of translocation of ${ }^{14} \mathrm{C}$ differed, being greater in barnyardgrass than in rice. Rice retained a greater part of the absorbed ${ }^{14} \mathrm{C}$ radioactivity in its roots than did barnyardgrass. Metabolic activity was much greater in both the shoots and roots of rice. Rice also converted simetryne in significantly greater amounts to watersoluble metabolites and methanol-insoluble residue as well as to dichloromethane-soluble metabolites.

It was concluded that the selectivity of simetryne in root application was mainly due to the differences in the metabolic activity in roots and shoots and the rate of translocation from roots to shoots.

Acknowledgements : The authors express their appreciation to $\mathrm{Mr}$. A. Miura for technical assistance and to Ciba-Geigy Japan Ltd. for its generosity in supplying the ${ }^{14} \mathrm{C}$-simetryne and other related $s$-triazine compounds for this study.

\section{References}

1) Ashton F.M., G. Zweig and G. Mason: The effect of certain triazines on ${ }^{14} \mathrm{CO}_{2}$ fixation in red kidney beans. Weeds 8 (4), 448 451 (1960).

2) Кohama S., J. Sakita, H. Mastumoto and K. Ishizuka: Selective mode of action of $s$-triazine herbicides $\mathrm{III}$ : Effects of simetryne on photosynthetic reactions. Weed Res. Japan 25 (Suppl.), $117 \sim 118$ (1980).

3) Matsumoto H. and K. Ishizuka: Herbicidal 
selectivity of foliar-applied simetryne: Its absorption, translocation and metabolism in gramineous plants. Weed Res. Japan 25 (3), 185 193 (1980).

4) PAPE B.E. and M. J. ZABIK: Photochemistry of selected 2-chloro and 2-methylthio-4,6-di (alkylamino)-s-triazine herbicides. J. Agr.
Fcod Chem. 18 (2), 202 207 (1970).

5) Shimabukuro R. H. and H. R. Swanson: Atrazine metabolism, selectivity and mode of action. J. Agr. Food Chem. 17 (2), 199 205 (1969).

(Received July 2, 1981)

\title{
シメトリンの根部処理における選択作用機構：イネ科植 物におけるシメトリンの吸収・移行・代謝
}

\author{
筑波大学応用生物化学系 松本宏・石塚 皓造
}

摘 要

シメトリンの根部処理時における選択作用機構について検討した。まず，水耕法により，3葉期に達した 6 種のー ネ科植物を供試し，それらの根部より各濃度のシメトリンを吸収させ，その後の生育を調査した。その結果，シメト リンは用いた濃度範囲において供試植物間に選択性を示し，トウモロコシおよびイネは抵抗性であり，シコクビエ， メヒシバ抢よびタイヌビエは感受性であった。また，コムギはこれらの中間的な性質を示した。

上記 6 種のイネ科植物からシメトリン抵抗性のイネおよび感受性のタイヌビエを供試して， ${ }^{14} \mathrm{C}-$ ーメトリンの吸収 ・移行および代謝について検討した。根部からの吸収速度は両植物間でほとんど差がみられず，また放射能の体内分 布にも差はみられなかった。しかし，根部から茎葉部への移行率はタイヌビエにおいて高く，この差が選択性発現の 一因となると考えられた。シメトリンの代謝においては両植物間において顕著な差がみられ，イネの根部・茥葉部共 に，水画分および未抽出残渣画分への変化の割合がタイヌビエのそれらより大きかった。またジクロルメタン画分中 における末変化のシメトリンの割合は，イネ体内の量がタイスビエ中より少なく，両植物のシメトリン代謝能力には 差のあることが認められた。これらの結果から，代謝能の差も選択性発現の一因となると考えられた。また根部処理 時の選択性の発現にあたっては, これらの植物の根部が重要な役割を果たしていると考えられ，イネの根におけるシ メトリンのより高い保持能と分解能は, その抵抗性に大きく寄与しているものと思われた。以上の結果から, 根部処 理したシメトリンの選択作用性は, 根部および茎葉部内代謝の差と茎葉部への移行率の差によって生じると考えられ た。 